\title{
Short Communication: Lugol's iodine test on Rafflesia patma-Tetrastigma leucostaphylum intersection tissue for preliminary starch visualization
}

\author{
ADHITYO WICAKSONO ${ }^{1, \nu}$, SOFI MURSIDAWATI ${ }^{2, v \varphi}$ \\ ${ }^{1}$ Division of Biotechnology, Generasi Biologi Indonesia Foundation. Jl. Swadaya Barat no. 4, Gresik 61171, East Java, Indonesia. \\ "email: adhitwicaksono@genbinesia.or.id; adhityo.wicaksono@gmail.com \\ ${ }^{2}$ Research Center for Plant Conservation and Botanic Gardens, Indonesian Institute of Sciences. Jl. Ir. H. Juanda No.13, Bogor 16022, West Java, \\ Indonesia. Tel.: +62-251-8311362, 8336871, ^^email: sofi.mdawati@gmail.com
}

Manuscript received: 19 July 2020. Revision accepted: 26 August 2020.

\begin{abstract}
Wicaksono A, Mursidawati S. 2020. Short Communication: Lugol's iodine test on Rafflesia patma-Tetrastigma leucostaphylum intersection tissue for preliminary starch visualization. Nusantara Bioscience 12: 91-96. As holoparasitic plant, Rafflesia has no recognizable plastid genome, but it has plastid-like organelle. Despite the fact that it obtains nutrients from host plant, it is unknown if Rafflesia stores primary metabolites, such as carbohydrates, from its host. A study was performed to visualize the starch in Rafflesia patma Blume proximal tissue which was intersected to its host root, Tetrastigma leucostaphylum (Dennst.) Alston, using modified Sachs' test with Lugol's iodine. The result revealed the absence of blackening in the R. patma tissue caused by starch reaction with the iodine, but occurred in the root cortical tissue of T. leucostaphylum. The absence of starch in $R$. patma tissue indicated that possibly the plastid-like organ has no similar function to amyloplast, and starch is not used for storage in the flower. It is likely that $R$. patma relies completely on the host's photosynthate to maintain the flower metabolism during anthesis period. However, detailed histochemical analysis for starch or carbohydrate is needed for confirmation whether the starch is existing even in small quantity, and molecular genetic observation on sucrose intake and flowering (anthesis) regulatory genes will also be required to confirm if Rafflesia takes the photosynthate directly from its host and possibility if Rafflesia coordinates the formation of flower bud and anthesis between the endophytic tissues to prevent overexploitation of nutrients from its host.
\end{abstract}

Keywords: Amylum, carbohydrate, Lugol's test, metabolite, Rafflesiaceae

\section{INTRODUCTION}

Rafflesia is a holoparasitic plant that relies completely on its host to obtain nutrients. Its floral organs are completely modified with minimalistic endophytic tissue on the early stage of the growth (Nikolov et al. 2014; Mursidawati et al. 2019), while the flower is equipped with simple vascular bundle with only xylem and vascular parenchyma (Mursidawati et al. 2020). To add the oddity of the plant, it has no recognizable plastid genome upon study on Rafflesia lagascae Blanco, but there are plastidlike organelles with no endomembrane system with dubious functions (Molina et al. 2014). The plastid genome is possibly lost during the evolution of holoparasitic plant.

Rafflesiaceae group (consisted of Rafflesia, Rhizanthes, and Sapria) has been existed since approximately 95.02 million years ago (Bendiksby et al. 2010). Also, from the same study, Rafflesia genus itself was separated from Rhizanthes 81.67 million years ago, which previously the group separated from Sapria in 95.02 million years ago; all of these were in the Cretaceous period (145-66 million years ago) of the Mesozoic era. To add more to the conundrum, its host Tetrastigma was separated from its relative of Vitaceae, Cayratia around 50.6 million years ago (Chen et al. 2011) which was in Paleogene period (6623 million years ago) of the Cenozoic era. It is unclear what happened between 44.42 million years (which transgress between Cretaceous-Tertiary era boundary), and this raises the question of how and when Rafflesiaceae started to develop its parasitic lifestyle.

The nutrients obtained by holoparasitic plant are originated from the host's photosynthetic metabolites, sugar, or carbohydrate. Starch is a major storage component for carbohydrate, and stored in plants as either transitory of impermanent starch which accumulated in the photosynthetic period and degraded at night, and the semipermanent starch storage in starch accumulating organ (Streb and Zeeman 2012). In flower, starch is processed (accumulated and degraded) during pollen and stamen development (Hedhly et al. 2016). It is unknown if such starch processing also occurs in Rafflesia especially since no previous study was done to unravel the starch biosynthesis, storing, and degradation in Rafflesia. The only known thing stored in the flower organ would be secondary metabolites (Sofiyanti et al. 2008), which contributes to flower coloration (Mursidawati et al. 2020), despite it is unclear if the metabolites are Rafflesia or host in origin. As Rafflesia flower blooms for about 5 days (pers. observ. for R. patma Blume; Patiño et al. 2002 for $R$. tuan-mudae Becc.), and the flower itself is succulent and large, it could be possible if it has a storage system which makes the flower thrives for a period of anthesis other than 
simply relying on its xylem-based nutrient transport from its host phloem (Mursidawati et al. 2020).

No previous study has covered the existence of starch storage in Rafflesia. Despite the possibility that Rafflesia generative organ might not be storing primary metabolites like carbohydrates, there should be any possibilities in the proximal area of the flower where it could be derived from stem, or where the pollen area is found. The proximal region of the flower bud (cupula) might also serves as stem analog and might be used as a storage compartment, despite structurally different and even has different shapes of vascular bundles from the stem of dicot (Mursidawati et al. 2020).

This study observed the possible starch distribution on Rafflesia patma Blume tissue area where it connected with its host Tetrastigma leucostaphylum (Dennst.) Alston despite flower bud was used, and it is unclear if the flower is male or female (hence to compare it to the pollen and stamen on Arabidopsis in the study by Hedhly et al. (2016). A simple test, a modified Sachs' iodine test was performed, and followed with visual observation for this preliminary examination. If starch granules are available, it might provide clues on Rafflesia storage organ or possible storage function on Rafflesia cell or organelle.

\section{MATERIALS AND METHODS}

This study was done in October 2017. The sample of Rafflesia patma young flower bud (the flower bud was approximately 6 months old) with diameter around $3 \mathrm{~cm}$ from grafted Tetrastigma leucostaphylum in the same plant as in the other study (Wicaksono et al. 2017; Mursidawati et al. 2019; Mursidawati et al. 2020) was taken along with some incision of Tetrastigma leucpstaphylum root where it grew. One big cut in the proximal part of the bud, where the host-parasite tissue is connected, was made using a scalpel (approximately within area of $3 \times 2 \mathrm{~cm}$ ) with thickness of approximately $1 \mathrm{~mm}$ (Figure 1.A, cut into 1.B).

\section{RESULTS AND DISCUSSION}

\section{The macroscopical and microscopical observation}

The procedure was the modification of Julius Sachs method (Sach 1864 cit. Kutschera and Niklas 2017; Nugroho et al. 2013), which normally performed on leaf to detect photosynthetic-derived starch. The protocol was started by boiling the leaf to deactivate the tissue, thus preventing any possible metabolic responses as the enzyme was already deactivated, then soaked on Jean Lugol's iodine $\left(\mathrm{I}_{3} \mathrm{~K}\right.$; Lugol 1829 cit. Starke 2009). A tissue slab was placed in a glass flask filled with boiling hot water $\left(100^{\circ} \mathrm{C}\right)$ for 1 minute to terminate the cellular activities which may lead to undesired enzymatic reaction including phenolic oxidation. The tissue slab was then strained and then soaked on Lugol's iodine solution for approximately 1 minute with enough volume to soak the slab on a glass flask (Figure 1.B). The color change was observed and documented macroscopically and microscopically on stereomicroscope using Nikon SMZ-10A.
The tissue of $R$. patma-T. leucostaphylum after treatment with Lugol's iodine (Figure 1.B) revealed a clear separation of which tissue stored starch, indicated by black coloration only in T. leucostaphylum tissue (Figure 1.C and D). The tissue part of T. leucostaphylum, which was also taken during the sampling, is the cortex region of the vine root that is extruded during the final development of the $R$. patma flower bud tissue along with smaller part of the periderm tissue (Mursidawati et al. 2019). The cortex region comprises of the parenchyma tissue, which is specialized to store starch from the photosynthesis (Beck 2010).

Under stereomicroscope (Figure 2), the cells in $T$. leucostaphylum parenchymal tissue also revealed dots of black where starch globules have possibly existed. These dots were absent in the part of $R$. patma flower bud tissue. The brownish coloration in Figure 2, R. patma tissue might be due to higher accumulation of secondary metabolites, such as tannin (Sofiyanti et al. 2008; Mursidawati et al. 2020). This metabolite accumulation is also visually visible in the distal part of the incised flower bud, as seen in pinkish coloration (Figure 1.B and C).

\section{Discussion}

From the study, the cells in the R. patma tissue did not seem to possess starch granule as no dark-colored granules observed in the parasitic tissue, compared to the host cortical tissue. This finding suggests that the plastid-like organelle revealed in the study by Molina et al. (2014) seems to not possess the utility to store starch as in amyloplasts or chloroplast. Possible use of Rafflesia plastid-like organelle could be for other metabolite storages (similar to chromoplast). However, it is never been explored if Rafflesia has carotenoid pigment, which commonly stored in chromoplast and chromoplast can be differentiated from chloroplast (Bian et al. 2011), amyloplast, or undifferentiated proplastid (Jarvis and Lopez-Juez 2013). Although in Molina et al. (2014), the fragments of genes found in the R. lagascae are only limited to photosynthetic genes, such as ATP-synthase (atp), NADH-dehydrogenase-like complex ( $n d h)$, photosynthetic electron transport (pet), photosystem I reaction center ( $p s a)$, photosystem II ( $p s b)$, and RuBisCO large subunit $(r b c L)$. However, it is unclear if the plastid-like organelle in Rafflesia is the proplastid, which remains undifferentiated since the early stage of flower development because of lacking differentiation genes. The chloroplast in plants is differentiated from proplastid in the light (Jarvis and Lopez-Juez 2013). However, despite Rafflesia is constantly exposed to the light, none of the differentiation seems to take place. As starch biosynthesis plastid genes are also absent (according to the discovery in Molina et al. 2014), that explains the absence of starch in the R. patma sample. However, the size of plastid-like organelle in Molina et al. (2014) is very small, around $1 \times 0.5 \mu \mathrm{m}$ ovoid diameters, and nearly similar in morphology with mitochondria. Hence, it is possible that the existence of starch granule, if even existed, might be really small to see. A detailed histochemical analysis for starch or even simpler carbohydrates would be required to confirm the presence of starch in Rafflesia tissue even in small quantities. 


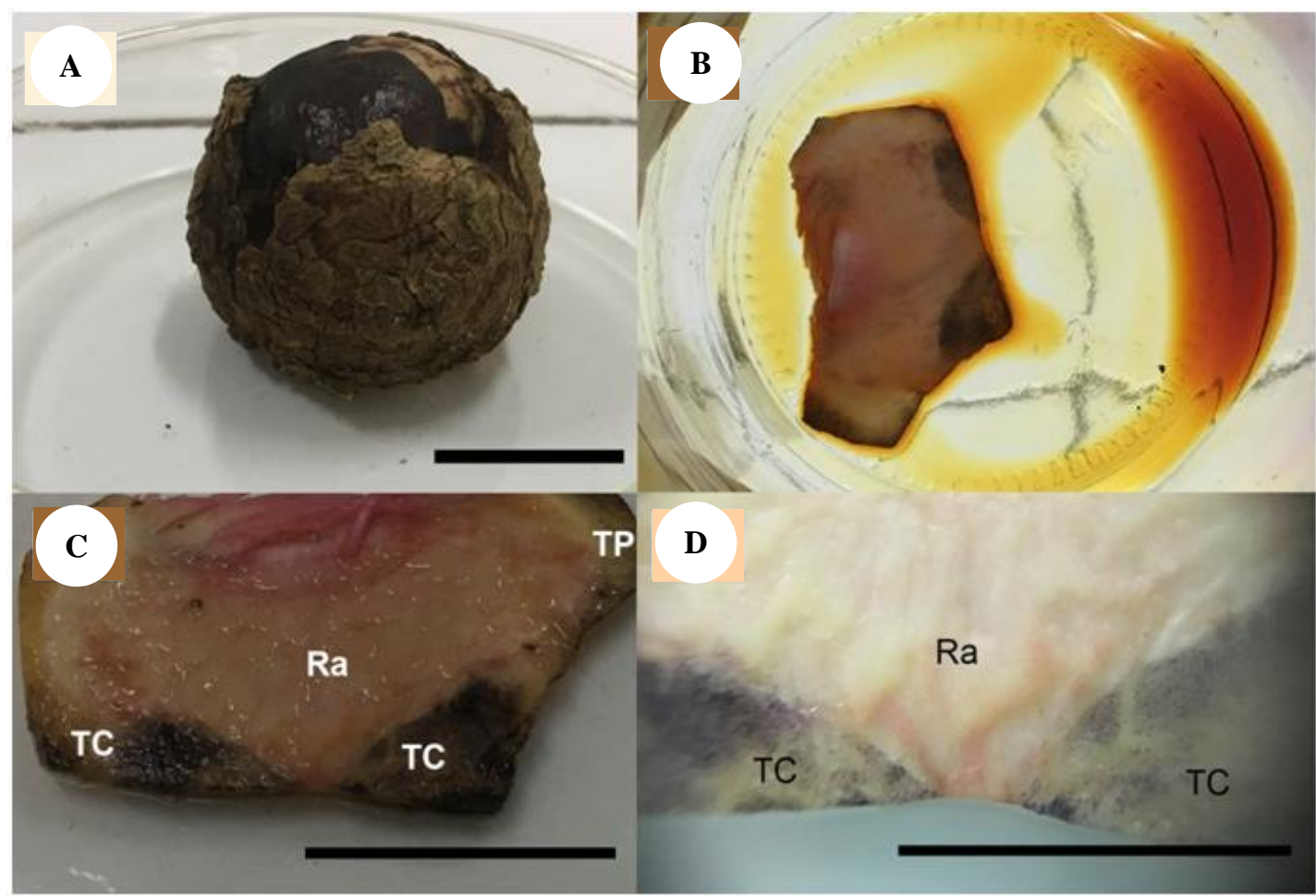

Figure 1. A. The R. patma flower bud; B. The tissue slab soaked in Lugol's iodine after previously placed in a flask with boiling water; C. The result shows the darkening of T. leucostaphylum tissue (TC and TP) with no change occurred in $R$. patma tissue (initially both have the same color); D. Enlarged view of Figure 1.C. Tissue slab in Figures 1.B, 1.C, and 1.D were the same. The image contrast was enhanced for Figure 1.D. Notes: $\mathrm{TC}=T$. leucostaphylum cortical parenchyma tissue, $\mathrm{TP}=T$. leucostaphylum sub-peridermal cortical parenchyma tissue, $\mathrm{Ra}=R$. patma bud tissue. Scale bars $=1.5 \mathrm{~cm}$.

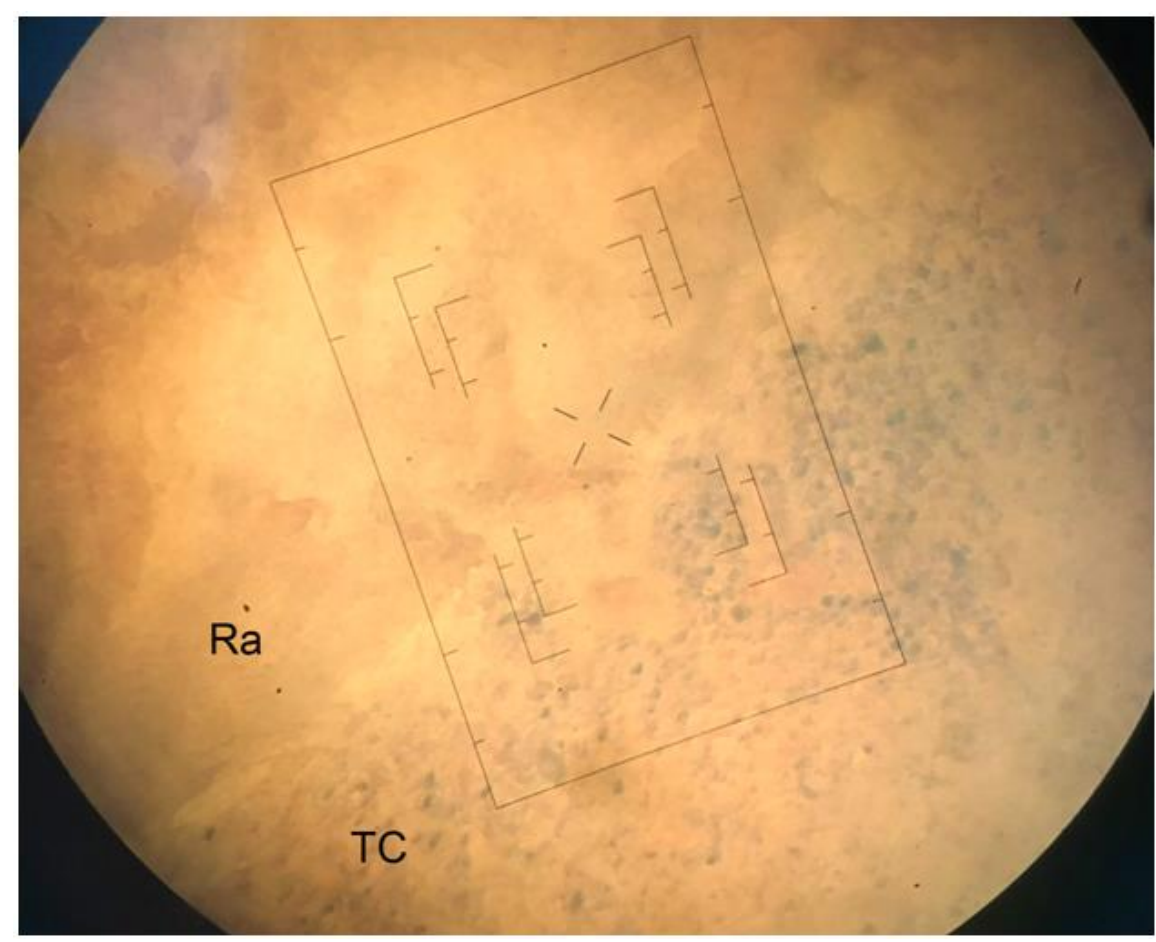

Figure 2. View under stereomicroscope, showing the Lugol's iodine stained cells with starch. TC = T. leucostaphylum cortical parenchyma tissue, $\mathrm{Ra}=R$. patma bud tissue. Image saturation level and color tone are increased to clearly view the blackened cells vs. non-blackened cells. The rectangular lens micrometer length size is $12 \times 24 \mathrm{~mm}$ (the outermost rectangle). 
Starch is stored carbohydrate in plants normally made from photosynthesis. Starch is a polymer consisting of glucose monomer chained with an $\alpha$-1,4-glycosidic bond on one to another, and comprising linear-chained amylose dominated with $\alpha-1,4$-glycosidic bond and branch-chained amylopectin with $4 \%$ of $\alpha-1,6$-glycosidic branchpoint (Kossmann and Lloyd 2000). The amylose linear chain has greater affinity towards iodine molecules (which was used in this study), and the complex have wavelength of maximum absorption around $620 \mathrm{~nm}$, which resulting in dark blue coloration (Kossmann and Lloyd 2000). The precursor component of starch biosynthesis in a plant cell is fructose 6-phosphate resulted from the Calvin-Benson cycle, using plastidic enzymes to convert it to glucose 6phosphate (with phosphoglucose isomerase), then to glucose 1-phosphate (with phosphoglucomutase), then to ADP-glucose (with ADP-glucose pyrophosphorylase), and finally, ADP-glucose was then converted into starch with starch synthase, which stored as starch granules (Bahaji et al. 2013; Hedhly et al. 2016). Alternatively, if the photosynthetic assimilates from Calvin-Benson cycle is about to be stored in other organelles, such as amyloplast, or even transported to other tissue before stored as starch, it required triose phosphate (glyceraldehyde 3-phosphate) transport into cytosol which later synthesized using cytosolic enzymes to become glucose and then sucrose (Bahaji et al. 2013). Simple carbohydrates could then enter amyloplast in three forms using two respective amyloplastic transporters before converted into starch: as hexose phosphate (glucose 6-phosphate, entering using glucose 6-phosphate transporter), and as ADP-glucose reprocessed from sucrose (with ADP-glucose transporter) (Beckles and Thitisaksakul 2014). These starches in the cortical region of the root (in this case, T. leucostaphylum root), which filled with parenchyma tissue, are stored for food storage in form of starch granules (Beck 2010). As none of these starches biosynthetic pathway was found in Molina et al. (2014) study, it is possible that Rafflesia directly taking the sucrose from Tetrastigma phloem and use it instead of storing it as starch within the flower tissue. The sample is a young flower bud, which further eliminates any suggestion of starch accumulation in the early stage of flowering. This also suggested that Rafflesia needs to bloom strategically to prevent the Tetrastigma from dying out during the days of anthesis, i.e. regulation of sucrose intakes, regulation of individual flower anthesis period, and signaling control between endophytic tissues for flower buds' formation and anthesis to prevent host photosynthate overexploitation. To confirm this suggestion, molecular genomic and transcriptomic studies will be required in the future.

In conclusion, from a brief observation conducted in this study, no sign of starch accumulation in $R$. patma young flower bud tissue. For future research, detailed histochemical analysis for starch or carbohydrate is needed to confirm whether the starch is present even in small quantities. Additionally, molecular genetic observation on sucrose intake and flowering (anthesis) regulatory genes will also be required to confirm the behavior of carbohydrate intake of Rafflesia from its host and possibility if Rafflesia coordinates the formation of flower bud and anthesis between the endophytic tissues. So far, molecular studies of Rafflesia are still limited on identification and detection of the endophyte within the host (i.e. in the study of Barkman et al. 2017) as well as on the floral development genes (i.e. in the study of Nikolov et al. 2013). By unlocking more genes for profiling, more information can be unraveled from the mysterious flower of Rafflesia.

\section{ACKNOWLEDGMENTS}

All authors contributed equally to the experiment and the writing of this paper. All authors declared no conflict of interest.

\section{REFERENCES}

Bahaji A, Li J, Sanchez-Lopez AM, Baroja-Fernandez E, Munoz FJ, Ovecka M, Almagro G, Montero M, Ezquer I, Exteberria E, PozuetaRomero J. 2013. Starch biosynthesis, its regulation and biotechnological approaches to improve crop yields. Biotechnol Adv 32 (1): 87-106. DOI: 10.1016/j.biotechadv.2013.06.006.

Barkman TJ, Klooster MR, Gaddis KD, Franzone B, Calhoun S, Manickam S, Vessabutr S, Sasirat S, Davis CC. 2017. Reading between the vines: hosts as islands for extreme holoparasitic plants. Am J Bot 104 (9): 1382-1389. DOI: 10.3732/ajb.1700117.

Beck CB. 2010. An Introduction to Plant Structure and Development $2^{\text {nd }}$ ed. Cambridge University Press, UK.

Beckles DM, Thitisaksakul M. 2014. Use of biotechnology to engineer starch in cereals. Encyclopedia of Biotechnology in Agriculture and Food. UC Davis. DOI: 10.1081/E-EBAF-120051354.

Bendiksby M, Schumacher T, Gussarova G, Nais J, Mat-Salleh K, Sofiyanti N, Madulid D, Smith SA, Barkman. T. 2010. Elucidating the evolutionary history of the Southeast Asian, holoparasitic, giantflowered Rafflesiacaea: Pliocene vicariance, morphological convergence and character displacement. Mol Philogenet Evol 57: 620-633. DOI: 10.1016/j.ympev.2010.08.005.

Bian W, Barsan C, Egea I, Purgatto E, Chervin C, Zouine M, Latche A, Bouzayen M, Pech J-C. 2011. Metabolic and molecular events during chromoplast biogenesis. J Bot 1-13. doi: 10.1155/2011/289859.

Chen P, Wen J, Chen L. 2011. Spatial and temporal diversification of Tetrastigma (Vitaceae). Gard Bull Singap 63: 307-327.

Hedhly A, Vogler H, Schmid MW, Pazmino D, Gagliardini V, Santelia D, Grossniklaus U. 2016. Starch turnover and metabolism during flower and early embryo development. Am Soc Plant Biol 172: 2388-2402. DOI: 10.1104/pp.16.00916.

Jarvis P, Lopez-Juez E. 2013. Biogenesis and homeostasis of chloroplasts and other plastids. Nat Rev Mol Cell Biol 14 (12): 787-802. DOI: 10.1038/nrm3702.

Kossmann J, Lloyd J. 2000. Understanding and influencing starch biochemistry. Crit Rev Plant Sci 19 (3): 171-226. DOI: 10.1080/07352680091139204.

Kutschera U, Niklas KJ. 2017. Julius Sachs (1868): The father of plant physiology. Am J Bot 105 (4): 656-666. DOI: 10.1002/ajb2.1078.

Molina J, Hazzouri KM, Nickrent D, Geisler M, Meyer RS, Pentony MM, Flowers JM, Pelser P, Barcelona J, Inovejas SA, Uy I, Yuan W, Wilkins O, Michel C-I, Locklear S, Concepcion GP, Purungganan MD. 2014. Possible loss of the chloroplast genome in the parasitic flowering plant Rafflesia lagascae (Rafflesiaceae). Mol Biol Evol 31 (4): 793-803. DOI: $10.1093 / \mathrm{molbev} / \mathrm{msu} 051$.

Mursidawati S, Wicaksono A, Teixeira da Silva JA. 2019. Development of the endophyte parasite, Rafflesia patma Blume, among host plant (Tetrastigma leucostaphylum (Dennst.) Alston) vascular cambium tissue. S Afr J Bot 123: 382-386. DOI: 10.1016/j.sajb.2019.03.028. 
Mursidawati S, Wicaksono A, Teixeira da Silva JA. 2020. Rafflesia patma Blume flower organs: histology of the epidermis and vascular structures, and a search for stomata. Planta 25: 112. DOI: 10.1007/s00425-020-03402-5.

Nikolov LA, Endress PK, Sugumaran M, Sasirat S, Vessabutr S, Kramer EM, Davis CC. 2013. Developmental origins of the world's largest flowers, Rafflesiaceae. Proc Nat Acad Sci USA 46: 18578-18583. DOI: $10.1073 /$ pnas.1310356110.

Nikolov LA, Tomlinson PB, Manickam S, Endress PK, Kramer EM, Davis CC. 2014. Holoparasitic Rafflesiaceae possess the mos reduced endophytes and yet give rise to the world's largest flowers. Ann Bot 114: 233-242. DOI: 10.1093/aob/mcu114.

Nugroho AW, Indrowati M, Sugiharto B. 2013. Peningkatan keterampilan proses sains melalui kegiatan laboratorium disertai strategi catatan terbimbing (Guided Note Taking) pada siswa kelas VIII E SMP Negeri Surakarta Tahun Pelajaran 2010/2011. Bio-Pedagogi 2: 38-44. [Indonesian]
Patiño S, Aalto T, Edwards AA, Grace J. 2002. Is Rafflesia an endothermic flower? New Phytol 154 (2): 429-437. DOI: 10.1046/j.1469-8137.2002.00396.x.

Sofiyanti N, Wahibah NH, Purwanto D, Syahputra E, Mat-Salleh K. 2008. Alkaloid and phenolic compounds of Rafflesia hasseltii Suringar and its host Tetrastigma leucostaphylum (Dennst.) Alston ex Mabb. in Bukit Tigapuluh National Park, Riau: A preliminary study. Biodiversitas 9 (1): 17-20. DOI: 10.13057/biodiv/d090105.

Starke JA. 2009. 14. Application of Iodine Water Purification Tablets: Iodine's Efficacy against Cryptosporidium parvum. In: Preedy VR, Burrow GN, Watson RR (eds) Comprehensive Handbook of Iodine: Nutritional, Biochemical, Pathological and Therapeutic Aspects. Academic Press, Massachusetts, USA.

Streb S, Zeeman SC. 2012. Starch metabolism in Arabidopsis. The Arabidopsis Book 10: e0160. DOI: 10.1199/tab.0160

Wicaksono A, Teixeira da Silva JA, Mursidawati S. 2017. Dispersal of Rafflesia patma Blume endophyte in grafted host plant (Tetrastigma leucostaphylum (Dennst.) Alston). J Plant Dev 24: 145-150. 